\title{
IDEOLOGY IN MODERN RUSSIAN CONSTITUTIONAL PRACTICE
}

\begin{abstract}
The article focuses on Russian constitutional ideology with overview of its historical preconditions and analysis of recent significant cases of the Russian Constitutional Court. There is a discussion of gay activist Alekseyev's case and "foreign agents' law" case in constitutional practice as most significant examples of positivistic way of legal reasoning.

The paper argues that legal positivism through its form - legal formalism is the main ideology in the modern constitutional practice in Russia. This ideology is based on the assumption that constitutional justice can find social truth. German positivistic and Soviet Marxist views have strongly determined the modern Russian constitutional discourse.
\end{abstract}

Keywords: Constitutional court, constitutional reasoning, formalism, legal positivism, Russian constitution.

\section{INTRODUCTION}

In 2013 Valery Zorkin, President of the Russian Constitutional Court, wrote a monograph on Law from the perspective of global changes in which he broadly described the meaning of historical background and cultural uniqueness of a state through its legislation (Zorkin 2013). In his opinion, the historical approach gives the option to choose the right features in a social system. This is meaningful for the definition of the place of the Russian Constitutional Court nowadays in political and legal system of the state.

The institution of constitutional justice is recent for Russia, however the role of the Constitutional Court during last 20 years has become stronger in resolving politically and culturally complex questions such as: elections, self-governance, traditional role of women in society, gay rights, etc.

In this chapter I will analyze the historical and legal preconditions as well as, the recent constitutional practice of the Russian Constitutional Court as an evidence of its formalistic ideology.

In the first part, the historical and legal background of modern Russian constitutional practice is presented. This is followed by a case analysis that illustrates my presumption about the legal approaches used by Russian

* Novosibirsk State University, Russian Academy of National Economics and Public Administration (Siberian Institute of Management), arudt@mail.ru 
Constitutional Court. The hypothesis is that legal formalism is the dominant interpretative approach of the Russian Constitutional Court that served to a specific goal: to find one truth for society.

The words "constitutional ideology" and "legal formalism" recur throughout this article so let me to explain them.

As Sergey Pojarkov defines the constitutional ideology as not only a set of ideas but at the same time the world-view, values, rules and system of tolls for influence on social relations (Pojarkov 2013, 19). Theoretically there is the intention of the Russian multinational people in the ground of the national constitutional ideology (Khorunzhij 2014, 4). However, the constitutional ideology justifies the political domination, social injustice and social exclusion (Frankenberg 2006, 441). For the goal of this chapter I define the constitutional ideology as set of ideas and tools used by the constitutional court to serve the current interests of the state. In this meaning the legal formalism is a part of constitutional ideology.

Legal formalism depicts the law as a system of norms and rules, judicial decisions as the result of deduction from applicable rule. Michel Rosenfeld noted that new legal formalism "is properly considered to be a type of formalism to the extent that it maintains that something internal to law rather than some extralegal norms or processes determines juridical relationships and serves to separate the latter from nonjuridical social relationships, including political ones" (Rosenfeld 1998, 33). These don't make formalism 'evil'. Serious arguments show that it is in demand: "enhancing the predictability and stability of law and curtailing judicial discretion" (Matczak 2016, 3). Nevertheless, in Russian context formalism doesn't necessary connect with rule of law but with law supremacy.

In the legal literature there are attempts to examine the effectiveness of Russian Constitutional Court functioning through judicial decisions. For instance, Jane Henderson analyzed the unique case of the constitutionality of the Communist Party of the Soviet Union compared with the Russian Communist Party in 1992 (Henderson 2007). Marie-Elisabeth Baudoin found the factual approach of European judicial practice as a test of proportionality and "reserves of interpretation" in Russian constitutional convention (Baudoin 2006). James Richardson and Marat Shterin observed the constitutional courts' cases under religious freedom and freedom of association for religious organizations in a comparison of Russia and Hungary (Richardson, Shterin 2008).

Methodologically, I decided to analyze two recent cases from the Russian constitutional practice. Both were continued at international legal level in the form of applications to the European Court of Human Rights (ECtHR). I will examine the case of gay activist Nikolay Alekseyev and the foreign agents' law as two recent cases in which the Russian Constitutional Court has dealt with a set of international human rights provisions that could stimulate it to use all possible interpretative tools to find the balance between private and public interests. The significance of these cases is also rooted in its connection with European legal doctrine and ECtHR practices. 


\section{DEVELOPMENT OF CONSTITUTIONAL COURT OF RUSSIAN FEDERATION AS OFFICIAL INTERPRETER}

The idea of a special body with the function of constitutional review was implemented in the Constitution of the USSR in 1988 leading to the establishment of a Committee of Constitutional Supervision (Butler 1991). In 1990 the Supreme Council of USSR elected 25 Committee members, yet in December 1991 they voluntarily ceased the existence of the same body. In parallel, in the summer of 1991 the Constitutional Court of the Russian Federation was created and started its activity in October 1991. As Alexei Trochev mentioned: "[d]esigning, redesigning, and staffing the Russian Constitutional Court was an arduous political process in which reformers and conservatives simultaneously clashed and cooperated to benefit from constitutional review" (Trochev 2011).

The main structure and jurisdiction of the Russian Constitutional Court was formulated in the Constitution of 1993. According to the article 125 of the Russian Constitution, the Constitutional Court has the right of the official interpretation of the act, through a special procedure at the request of the President, Government and chambers of the federal and regional parliaments. However, in Russian constitutional theory, the concrete constitutional review practice in terms of complaints from individuals of the Constitutional Court is studied as a "shadow" interpretation or even a transformation of the constitutional norms (Anichkin 2010).

The 2010 Russian Constitutional Court reform included: changes in the organization of the Court (the chambers were ceased) and in procedural rules of concrete constitutional review (the amount of cases without hearing were expanded). Moreover, according to its amendments, the citizens have the right to claim to the Constitutional Court only after the judicial decisions under their cases in the courts of general jurisdiction or arbitration courts in Russia. The judicial decision before the Constitutional Court of Russia must include the reference to legal provisions that are under the question of constitutional confirmation. This decision, at the same time, could be appealed in courts of general jurisdiction or arbitration courts according to procedural laws. After the petition's admission, the Constitutional Court of Russia notifies the court that has adopted the latest judgment on the case and the court considering a case for which this court judgment may be of relevance. This is a legal meaning as the "law that has been applied in a specific case" whose consideration has been completed in court (the jurisdictional court level does not matter). The next significant criterion for the admission of the petition is the presence of a violation of rights and freedoms by the applied law (art. 3, 96 Federal Constitutional Law On Constitutional Court of Russian Federation 1994).

Before the latest reform, the citizens had the right on the constitutional petition after a decision by administrative bodies and when the case was under 
consideration in the courts but there was no decision yet. However, the broad interpretation of "citizen" still exists and allows the procedure of making constitutional appeals by foreign citizens, stateless persons or any legal types of associations of citizens. Another achievement of previous constitutional practice that has been continued, is the broad understanding of term "law" which could be the object of constitutional control. In theory, however, it is also presented the claim to extend this understanding (Nesmeianova 2004). From these reforms I see that the Court has parallel tendencies in strict and broad construction of the procedural rules. For strict interpretation the instrument of law-making is used and for broad construction the Court uses the judicial practice.

The Federal Constitutional Law of 1994 on the Constitutional Court of Russia allows to carry out a constitutional review through three types of acts: decisions on the merits of the case; decisions, which dismiss a case without hearing; decisions in the procedure of presidential impeachment (art. 71). The decisions on the merits of the case and without hearing are based on the special techniques of the constitutional interpretation. The important features of such decisions are that they shall be final, may not be appealed and shall come into force immediately upon pronouncement. The decision of the Constitutional Court of the Russian Federation shall be directly applicable and shall require no affirmation by other bodies nor officials. According to the Federal Constitutional Law of 1994 the legal force of the judgment of the Constitutional Court of the Russian Federation deeming an act to be unconstitutional may not be overcome by the new adoption of the same act (art. 79).

The legal positions in the judgments of the Constitutional Court play the crucial role for legal practice in Russia. Officially, the formal status of those elements of decisions is not defined, yet the Court and modern constitutional theory recognize their normative nature.

The nature of legal positions is broadly discussed in theoretical terms. The Judge of the Constitutional Court Gadis Gadzhiev called legal positions as "crystallized law", "legal source" "and legal principle for the solution of similar legal collisions" (Gadzhiev 1999, 22). Former Judge Boris Ebzeev noted that the legal positions of the Court are not the ordinary argumentation of the decision but the outputs as a result of constitutional interpretation (Ebzeyev 2000, 24-25) The theorist Vladimir Kriazhkov defined the legal positions as the legal-logical base of the courts' decision into resolution consisting of inferences and installations, which have common obligatory value (Kriazhkov 1999, 109).

In the judgment of 7 October 1997, the Constitutional Court of Russia pointed out that the provisions of a motivation part in a judgment of the Court which have constitutional interpretation or the interpretation of the constitutional meaning in laws are legal positions and have an obligatory character. In this case the Constitutional Court referenced the article 6 of the Federal Constitutional Law "On Constitutional Court of Russian Federation", however under inspection in 
this article the mention of legal position is absent. Here the obligatory character of Constitutional Courts' decisions is maintained. The Court gives broad interpretation to article 6 and expands the compulsory character to legal positions which are a part of judgments. In the resent judgment of 8 November 2012 the Court pointed out again that courts of general jurisdiction and arbitration courts must follow the Constitutional Court's decisions and the identified legal positions (Constitutional Court's Judgment 2012, №25-P).

Sergey Belov considers the changing in usage of legal positions of Russian Constitutional Court by other judicial bodies. He noted that, generally, courts comply and use these positions however, not systematically. The practice show us that courts use Constitutional Court's legal positions spontaneously and behindhand (Belov 2014). For instance, the Federal Arbitration Court of the Northwestern District in its judgment of 20 March 2014 essentially recognizes the need to prove the guilt of the legal entity (Case №A56-56482/2013). The arbitration court used the legal position set out in the Judgment of the Constitutional Court of the Russian Federation of 27 April 2001 №7-P. According to the Constitutional Court's position, legal entities cannot be denied the opportunity to prove that the violation of the rules has been caused by extraordinary, objectively unavoidable circumstances and other unforeseeable, insurmountable for the data subjects concerning obstacles beyond their control. However, in similar cases arbitration courts have often come to the same conclusion without references to legal positions of the Constitutional Court or even didn't pay attention to the evidence of legal entity's guilt.

The comparison of theoretical and practical estimations of the Constitutional Court's legal positions is significant. Despite the attempts of constitutional judges and scientists to show the normative character of these positions the real situation bring to light its neglect. This situation is connected with the question of judicial autonomy of Russian Constitutional Court. Courts in many nations have seen a rise in terms of their authority and independence in recent decades. However, the Russian Constitutional Court has been strongly affected by the political situation that doesn't allow showing independence. Anders Fogelklou named this situation as "fundamental paradox" of Constitutionalisation in post-Communist states: "The constitution is adopted in order to introduce political and societal changes, and at the same time, it must not deviate too much from the political and social environment in which it is supposed to function. But this latter demand is problematic. The potential positive function of a constitution as a legal transplant capable of promoting change could be lost" (Fogelklou 2003, 181, 186).

Formally, the Constitutional Court of Russia is an independent body however it has a lot of critics among scientists and practitioners in constitutional law. In comparison with the active and powerful Hungarian Constitutional Court, Russia: "had an activist court that was forcibly closed for political reconstruction in 1993 and reopened only in 1995 under severe constraint. The Russian 
Constitutional Court then kept its head down in fractious national politics and has survived" (Scheppele 2003, 219-220).

At the same time, during its twenty years of activity, the Court, accomplished substantially in terms of human rights development and bringing about change in Russian economic and political sectors: "By using small-scale delimitations instead of issuing so many large opinions on important political matters, the court has bought itself some space for developing constitutional ideas and perhaps having a bigger effect in Russian political life in the long run." (Sheppele 2003, 232). "On the one hand, decisions adopted since the end of the 1990s show the use of new reviewing tools, sometimes borrowed from other supranational jurisdictions, which enable the Court to somehow participate in the rationalisation of the constitutional system. On the other hand, to try and reduce gaps in the legal system and to regulate its internal contradictions, it has adapted its methods of control so as not to destabilise the state or legal order. With the benefit of experience over 10 years, the Court case law is becoming richer at both a substantial and methodological level" (Baudoin, 689).

In early December 2009 Anatoly Kononov (one of the longest-serving Constitutional Court judges who often had the special opinion during judgments) resigned his tenure starting with 1 January 2010. This case is a mirror of the question of independence of the Court. Kononov as an independent lawyer resigned as a judge, as tired of fighting with the system. Another judge of the Constitutional Court of Russia Vladimir Yaroslavcev said in an interview to the Spanish newspaper El Pais that he feels himself "on the ruins of justice" and that during the rule of Vladimir Putin and Dmitry Medvedev the courts in Russia work as an administrative instrument of executive power (News of "Ekkha Moskvy" Judge of the Constitutional Court will leave Constitutional Court early in the next year 2014).

The historical development of the Russian Constitutional Court was always in connection with power-building of the post-Soviet state and this fact cannot be neglected. In 1990s - early 2000s the Court served to strengthen the presidential power and executive branch to fulfill legal uncertainty. In the second decade of the 2000 s, when the common structure of political power was fixed, the new tasks of constitutional justice were found - to construct political and cultural identity under the principle of "sovereign democracy" (Polyakov 2007, 59). The question is how did the changes in the status and content of Constitutional Courts' position influence on its interpretational approaches. 


\section{INTERPRETIVE METHODOLOGY AND EVIDENCES OF LEGAL FORMALISM IN MODERN CONSTITUTIONAL PRACTICE}

The researchers recognize the fact that Russia shares the same Western legal tradition as other European states. Bill Bowring stated: "Russian law since the twentieth century is German law; the Russian Constitutional Court is modeled on German Bundesverfassungsgericht and the 1993 Russian Constitution bears strong traces of the German Constitution, especially the Sozialstaatsprizip, the constitutional commitment to a social state" (Bowring 2013, 206-207).

This tendency is similar to Central European states' legal cultures. Rafal Mańko explains that in Central European states the method in legal education, practice and scholarship has been dogmatic and positivistic: "Central European legal culture was always in the shadow of the West, and in this context, West meant, first and foremost - Germany and Austria" (Mańko 2005, 527, 531). However, as well as in other Central and Eastern Europe socialism restrained Russia from legal realism, which had its greatest influence on the United States and Western European legal cultures. Csaba Varga considers Central and Eastern European legal mentality as it still exists in terms of its:

continuity of text-centrism in approach to law, with the law's application following the law's letters in a quasi-mechanical way. Consequently, what used to be legal nihilism in the Socialist regime has turned into the law's textual fetishism in the meantime. This is equal to saying that facing the dilemma of weighing between apparently contradictory ideals within the same Rule of Law, justice has in fact been sacrificed to the certainty in/of the law in the practical working of the judiciary. Especially, constitutional adjudication mostly works for the extension of individual rights while the state as the individuals' community is usually blocked in responding challenges in an operative manner (Varga 2013, 207).

These specificities determine modern Russian legal culture as a mix of postSoviet heritage and positivistic tradition. It is not hyperpositivism as in Soviet times (Mańko 2013, 207). Russian lawyers live in the German legal tradition and think in a deductive direction when the analysis of facts depends on the general legal norms which they should follow. The lawyers' level of professionalism and fairness of decision are connected with the quality of the facts' correlation with the norms. There is no place for the changing of the meaning of the norms towards ordinary legal practice. In such a situation the constitutional practice could be presented as extraordinary for Russian legal thinking. However, in practice the transformation of the legislator's will as expressed in the law is highly rare and complex for constitutional judges. As ordinary judges they prefer to wait for formal legal change rather than to change the judicial practice by their own decisions (Marchenko 2011).

In the interpretive practice of the Russian Constitutional Court, the domestic law (Constitution, federal and regional legislation, case law of domestic courts, case law of the Constitutional Court and other high courts) is broadly used. 
However, one can notice a tendency towards the development of references to the international law (international treaties (conventions, declarations, pacts, etc.), general principles, recommendations, case law), and human rights law in particular. For instance, the first reference to the European Convention on Human Rights and Fundamental Freedoms took place even before its official ratification by judgment on 4 April 1996 (Constitutional Court’s Judgment 1996 №9-P). In this decision, the Court pointed out that freedom of movement is recognised by numerous international human rights acts including the European Convention. The international case law has been used more actively in argumentation of the Constitutional Court in last. This trend is particularly visible in cases when the Court is searching for a balance of public and private interests and seeks to strength its position with the support of the ECtHR decisions.

The frequent praxis of European human rights law can be examined in terms of the broader discussion of its own constitutionalisation. As C.J. Van de Heyning noted the European Convention on Human Rights might well become a "constitutional instrument of European public law" (Van de Heyning 2012, 128). The same the ECtHR's claimed in the case Loizidou v. Turkey from 1995 (no 15318/89, 23 March 1995, para 75). Wojciech Sadurski alleged that it has become fashionable to call the ECtHR as the "constitutional court" for Europe (Sadurski 2012, 1). Famous scientists and practitioners such as: Steven Greer, Luzius Wildhaber attempt to discuss this idea through the usage of the modern understanding of constitutionalism and constitutional order (Wildhaber 2007, 2012; Greer 2012). The extensive diversity of Member-states of the Council of Europe as a consequence of the accession of Central and Eastern European states is the biggest challenge of the enlargement of the ECtHR power. Additionally, the question of the erga omnes effect of the ECtHR's judgments remains open.

Russia ratified the Convention in 1998. The Russian Constitution in article 15.4 established the principle of the supremacy of the "universally recognized norms of international law and international treaties and agreements of the Russian Federation" under the rules "those envisaged by law". Alongside EU members, Russia is also a Member of the Council of Europe and practices the human rights' interpretation in the light of the Convention. The Constitutional Court of Russia in this sense plays the main role in the implementation of doctrines and interpretation from ECtHR to the constitutional legal order into state.

For Russian constitutional practice the question of references to international law is sensitive in light of the specific role of the national legal order in social organization. The relations between Western law (particular European human rights law) and Russian law are described by the President of Russian Constitutional Court Valery Zorkin as both cooperative and competitive (Zorkin 2013, 454). His view is inspired by German classic philosophy (G. Hegel, I. Kant), Russian legal philosophy (Boris Chicherin, Vladik Nersesyants) and modern philosophers such as Pierre Bourdieu and Jürgen Habermas. These philosophical 
positions uphold the endeavor to argue that constitutional justice is a tool for finding the truth that not always correlates with the civil opinion. Moreover, the following claim is that this truth tends to be stable and should be protected by law. Consequently, for the purpose of achieving it, the judicial power must select "good" elements of social norms and other institutions and protect them. As the former judge of Russian Constitutional Court Tamara Morshakova said the Russian "tradition has the desire to have the truth and fairness in law" (Morshchakova 1995, 283-284).

This precise connection, between legal positivism and law, truth and fairness is carried forward and illustrated in the next section of this paper through an analysis of the case law in Russian constitutional practice.

\subsection{The Alekseyev case}

The Constitutional Court of Russia took decisions regarding the Alekseyev's lawsuit twice: once before the decision made by the European Court of Human Rights and once after it. Nonetheless, the approach as well as the central position of the Constitutional Court of Russia did not change. The following subsection of the paper will review the main facts of the Alekseyev case.

\subsubsection{Facts and court's decisions in the Alekseyev case}

Even though, in general terms the concrete circumstances of the cases in the two decisions of the Constitutional Court of Russia and the one of the ECtHR were different, for the purpose of this paper and our thesis, the analysis targets them as one entity. The reason for this unification is that the core arguments of petitioners and the substance of laws under proceeding did not change.

Mr. Nikolay Alekseyev is a gay rights activist in contemporary Russia. Together with other individuals he tried to organized marches, demonstrations and pickets in an effort: "to draw public attention to discrimination against the gay and lesbian minority in Russia, to promote respect for human rights and freedoms and to call for tolerance on the part of the Russian authorities and the public at large towards this minority".

The judgment on 19 January 2010 (№151-O-O) of the Constitutional Court of Russia found that the demonstrations and pickets in Ryazan organized by Nikolay Alekseyev did not receive permission from the local authority in 2009. Consequently, two other applicants were sentenced by the Ryazan district court to a fine, the reasoning being that they did a picket near a school with posters exhibiting slogans like: "Homosexuality is normal", "I am proud of my homosexuality". The legal ground of these limitations of freedom of assembly and expression in these cases was based on the regional law on administrative offenses and the law "For protection of morality of children in Ryazan region" which ban and punish the public actions for homosexual propaganda. 
According to the facts in the second constitutional case of 24 October 2013 (№1718-O), Nikolay Alekseyev was sentenced for an administrative offense: he made homosexual propaganda in Saint Petersburg, where the regional legislation has similar provisions as the Ryazan laws. As an applicant in constitutional cases Mr. Alekseyev asked for the recognition that the regional laws are non-conforming to the articles 15, 17, 19, 21, 29 and 55 of the Constitution of the Russian Federation. The applicant argued that these legal provisions allow the authorities to discriminate persons who want to take part in public events on the basis of their sexual orientation.

Between these two constitutional cases, the ECtHR recognized that the ban of Alekseyev's organization of public events on the issues of homosexuality and human rights of gays, lesbians, transgender people in Moscow during three years were not in accordance with the Convention and ruled that there has been a violation of Article 11, 13, 14.

\subsubsection{Methods and source of constitutional interpretation in the Alekseyev case}

An interesting observation is that in the second constitutional case, the Russian Constitutional Court did not change its motivation and interpretation based on European human rights law even after the judgment of ECtHR. Moreover, the motivation by the state authority in the ECtHR Judgment and in the one by the Constitutional Court in these cases was similar. The Constitutional Court used the reference to judgment of ECtHR in its second decision in the Alekseyev case however, this reference did not follow the aim of the correction to the previous legal positions. This stability in the argumentation could be estimated as the will to secure the traditional social values and protect the Russian understanding of minorities' rights in a national context while considering the historical preconditions on the ground.

In the first Decision of 19 January 2010, the Constitutional Court used the reference to the Convention just nominally without any references to the ECtHR cases nor the Recommendations of the Council of Europe bodies in terms of the protection of the rights of people of homosexual orientation. The main sources of constitutional interpretation in this decision were the Constitution of Russian Federation (in a formal way) and regional laws. The later source was used in a teleological interpretation as an attempt of the Court to formulate the legislative aim for the restrictions of freedom of expression. This aim is the protection of children health and moral development. The Court concluded that the legislator of Ryazan region has established measures "aimed at ensuring the intellectual, moral, and psychological safety of children, including a prohibition to make public actions aimed at propaganda of homosexuality". Children are persons "who because of their age lack the ability to independently evaluate" information deemed harmful by the Court and legislator. Consequently, in the view of the Court, the prohibition 
of such so-called propaganda cannot be considered as violating the constitutional rights of citizens.

Formal textualism in European human rights law's interpretation was founded on the discussion about possible limitations of the freedom of expression that might be necessary in a democratic society in order to uphold the interests of state security, territorial sovereignty, health and moral protection or justice, etc. The key element of these broader debate that was brought up in the motivation, charged with a highly volatile textual interpretation, is the "protection of morality". The Russian Constitutional Court had concluded that the limitation of public events that publicize or promote non-traditional sexual orientations is reasoned by the purpose to protect the society, especially the youth and children from the information that might be of harm for morality, and which try to define-as the Court sees it-the wrong attitudes of "social equality of traditional and non-traditional marriage relationships". As a result the claim of Alekseyev in this case was rejected by Constitutional Court of Russian Federation because, in their interpretation, there was no unlawful limitation of human rights.

In the decision of the Russian Constitutional Court on 24 October 2013 a similar direction of using European human rights law was conferred (Constitutional Court's Judgment 2013, №1718-O). The main sources for interpretation were twofold: a regional legislation and the Constitution of the Russian Federation. These focused on the same aim as previously mentioned - to identify the purpose of the regional legislation that bans a public events that promote non-traditional sexual orientations in a positive light. On the other hand, the Court mentioned in its decision the judgment of ECtHR on 21 October 2010 and subsequently gave its interpretation: "All persons without reference to their sexual orientation are under the protection of the Constitution of Russian Federation $[\ldots]$ and the Convention".

According to Russian Constitution, these points do not exclude the necessity to define the limitations of human rights while considering the balance of competitive constitutional values $($ art.17, 55). In this way the Constitutional Court of Russian Federation formulated an exception from the principle of nondiscrimination. In essence, on the one hand there is the freedom of expression of minorities and on the other hand the need to uphold the morality of the majority (as well as some of their rights such as: the right to bring up children; the right of the protection of moral beliefs) - the second becomes more significant. The Court concluded that in the current historical and social conditions the majority interests and values can justify the exception from the principle of non-discrimination.

This motivation and the direction of pragmatic interpretation of European human rights law are interconnected with the government authorities' position in the ECtHR judgment under Alekseyev case. But there are some obvious collisions in the interpretations of the Constitutional Court's and the ECtHR. In paragraphs 78 and 79 the ECtHR had noted that the argument of government that "propaganda 
promoting homosexuality was incompatible with religious doctrines and moral values of the majority and could be harmful if seen by children or vulnerable adults $[. .$.$] do not constitute grounds under domestic law for banning or otherwise$ restricting a public event". The ECtHR also stated that the government cannot "substitute one Convention-protected legitimate aim for another one which never formed part of the domestic balancing exercise".

The logic of the ECtHR was very clear: that for the acceptance and tolerance of a minority, the majority should permit them to express themselves. The role of government in this balance of interests and values is to protect the public order during such demonstrations, pickets, marches and other public events. Nevertheless, such logic was not a part of the motivation in constitutional cases in Russia.

Nowadays in the Russian regions the practice of the ban of homosexual public events is remains and is in accordance to the position of the Constitutional Court of Russia that has been described in this research. There are no alternatives for organizing of such public events - the ban is upheld without exception. An alternative that might lead to the achievement of the freedom of speech and of assembly for citizens like Alekseyev was absent in the argumentation of the Russian Constitutional Court. The Constitutional Court's decision was detected as institutional decision. This clearly constitutes an example of how this Court does not like to discuss the alternatives in sensitive questions because the truth should be one. This is so-called "magisterial" style of adjudication is typical for the Central and Eastern Europe (Mańko 2005, 542).

\section{2. "Foreign agents' law" case}

On 8 April 2014 the Russian Constitutional Court decided that the legal provisions about the recognition of the NGO which uses foreign financial resources and have a desire to act in political sphere as "foreign agents" is in conformity with constitutional principles and norms. The interpretation of European human rights law in relevant judgment is discussed in the upcoming section of this paper. This analysis is important because the ECtHR is working with the same case under "foreign agents' law" as a result of the common application from 11 Russian NGOs in 2013.

\subsubsection{Facts and court's decisions in "foreign agents' law" case}

In 2012 the Federal Assembly adopted the amendments to the Federal Laws "About Non - Governmental Organizations" and "About Civil Associations" regarding the new status for a part of NGOs in Russia which have been named in laws as "foreign agents".

According to Law, the NGOs that receive money or other property from foreign sources as well as participate (or have an intention to participate) in political activities on the territory of the Russian Federation shall be obliged 
to apply to the Ministry of Justice for state registration as nonprofit organizations acting as the foreign agents.

In 2013 the Russian Ombudsman has prepared the application to the Constitutional Court of Russia for the protection of rights of NGO "LGBT - kinofestival Bok o Bok" and three citizens - the chairpersons of Russian NGOs: Kostroma Centre of Public Initiatives; Amur ecological club "Ylukitkan" (this part of application was rejected after the information about results of cassation by Amur Oblast Court); and the Association of NGOs "For protection of rights of voters "GOLOS". At the same time the three applications were separately submitted by three Russian NGOs' chairpersons however under the same question about the constitutionality of legal provisions of foreign agents.

The facts in the cases of applicants showed their participation (personal or collective) in political activity in Russia in different forms: public debates, roundtables, information on the web pages, meetings with members of parliament. These NGOs had used or just had the will (as "GOLOS") to use the financial support from foreign foundations.

Each of these chairpersons of Russian NGOs were punished or warned about future punishment according to the provisions of the Federal Laws "About Non - Governmental Organizations", "About Civil Associations" and Administrative Code of Russia (Article 19.34) because they violated the obligation to notify the government about their status as foreign agents (Constitutional Court's Judgment 2014, №10-P).

The claim of the applicants to the Russian Constitutional Court was based on the argumentation that such limitation of the activity of a part of NGOs in Russia is not conform to the Constitution of the Federation as it brings about discrimination and contradiction with the principle of the legal certainty. Moreover, the applicants argued about the potential disproportionate punishment for them for the violation of legal provisions. According to Administrative Code the minimal size of the fine is 100000 rubles, around 1700 dollars (art. 19.34 Administrative Code of the Russian Federation 2001, №195-FZ).

The Constitutional Court in the judgment of 8 April 2014 decided that the legal provisions of Federal Laws about foreign agent status are in conformity with the Russian Constitution because it includes legal certainty, legitimate aim and presume the bona fides for Russian NGOs as foreign agents. At the same time the article 19.34 of Administrative Code did not include the possibility for a lower limit of punishment in the case of minor offense and here it stated that it is not in conformity with the Constitution of Russia. 


\subsubsection{Methods and source of constitutional interpretation in the case of "foreign agents' law"}

It is significant for the broader usage of international law in Russia that the 54-pages judgment of the Constitutional Court included multiple references to the ECtHR practice and Recommendations of the Parliament Assembly of the Council of Europe.

The paragraph 2 of the judgment of the Constitutional Court of Russia noted that the precedents of the ECtHR witnessed about the special meaning of the freedom of assembly in democratic societies and unreasonable limitation of it, has a negative impact on the NGOs activity and such practice is not conform with obligations of Member-States. In this paragraph the Constitutional Court also referenced one of the important Judgment of ECtHR in the understanding of the freedom of assembly - the case of Jehovah's Witnesses of Moscow v. Russia (2010). These references are doctrinally relevant and helped the Court to construct the framework for its decision. Moreover, in the same paragraph the Court also mentioned that the Article 11 of the Convention allows the limitation of the freedom of assembly in order to achieve several goals: state and social security; prevention of the disorders and crimes; for the recognition, respect and protection of rights and freedoms of others; protect the health and well-being and the satisfaction of the morality. An interesting contradiction to be observed is that while these provisions were used as an argument for the possible restriction of human rights, none of the previously mentioned purposes were actually proven to be at risk by the Russian Constitutional Court. Moreover, there is a lack of clarity in the judgment as to which one of these purposes they are referring, hence leading to a possible weakness of the decision itself.

The Constitutional Court used the reference to the European doctrine and precedents about legal certainty for the protection of the legitimate aim to secure public order from "foreign agent". The Court noted that the value phrase "foreign agent" is clear, well defined in law and adequate to the legitimate aim. In paragraph 3 and 3.2 the Constitutional Court relied on the Recommendations of the Committee of Ministers of 10 October 2007 with the Decision of the Committee of Ministers of the Council of Europe of 16 April 2003. The Court concluded that the European principle of the pluralism in legal regulation of NGOs status allows Russia to distinguish the NGOs who use the foreign support from those who are not.

In this judgment the Court paid much of attention to the purpose of legislator in the amendments to NGOs' legislation in 2012 (as a part of teleological approach). It pointed out that the construction "foreign agent" did not have a negative value from the state for such nonprofit organizations and follows the aim of financial transparency of political oriented activity in state. The simple way to prove the legitimacy of any law is to use the reference to the Preamble of the Russian 
Constitution stating that there is one source of power in state - the people and the representatives in Parliament translate peoples' will to laws. The legitimacy of law is in legitimacy of Parliament. The same reasoning was included in the Courts' motivation in this case. There is no statistical information about public interests being infringed in the case of special status NGOs or any issues that might arise in terms of the communication between citizens and NGOs who are using foreign support. There is just statement that such problems have public policy meaning. Without any relevant information in this sense it is hard to find the evidence that such public policy meaning is not just masked interests of national elites.

The case of "foreign agents' law" in Russian constitutional practice shows that the Constitutional Court freely uses the legal formalism and rationality to achieve a "legitimate aim". However, the legal analysis of legitimacy of such aim is poor and looks toward substitution of social interests with states' goal that could be equal to powerful groups' interests.

\section{CONCLUSION}

The legal analysis of politically and economically sensitive questions is a difficult task on its own for constitutional judges, not mentioning that at the same time they are under political and social pressure. These circumstances partly represent the reasons why these judges are restricted in choosing of the constitutional techniques and methodologies. Nonetheless, in the Russian constitutional practice there are examples of enlargement in usage of the international law as a tool for constitutional interpretation. However, the set of developing methodological approaches is not fully implemented. The Constitutional Court relies on ideologies of formalism and rationalism as adapted to the current economic, political and social development in Russia. The Court follows the idea around one truth in constitutional cases with the presumption that this truth is included in the axiomatically legitimate aim of legislators of Russia.

Both Russian Constitution and European Convention on Human Rights include general and broad reservations for limitation of human rights. Thus the Russian Constitutional Court selects convenient (not necessary relevant) ECtHR judgements to justify legislative designs. Following the conventional obligations, the Constitutional Court denied that the minorities themselves are a threat to society. There are formal refusals to recognize the restrictions as such.

The findings in this article should not be a reason to judge the Russian Constitutional Court as underdeveloped in constitutional interpretation because during its twenty years' of activity many Western constitutional theories and techniques were implemented in practice. For example, this includes the partial implementation of the principle of proportionality and idea about the balance of public and private interests (Gadgiev 2004; Dolzhikov 2012). 
Constitutional formalism in Russian legal practice is not unique and it shares similar evidence in Central and Eastern Europe where legal problems are simplified and restricted to legal collisions, legislators' will without correlation to social reality and context. Consequently, the Russian Constitutional Court used abstract and bold notions of social wills, social fairness, social interests, traditions as positive facts.

The legal formalism is a part of national constitutional identity's formation with one constitutional truth which the constitutional court can find. However, if the constitution is a civil agreement where in constitutional disputes there is no axiomatically right person for the constitutional court. While the courts focus for solutions, they might play the role of mediators. This idea is connected with future development of international human rights law and soft law regulation in this sphere. The mediation of the national and international interests, the interests of minorities and majorities, the interests of powerful groups and others is an intrinsic part of the constitutional justice mission.

\section{BIBLIOGRAPHY}

Anichkin, Yevgeny. 2010. Preobrazovanie Konstitutsii Rossiyskoy Federatsii i razvitie konstitutsionnogo zakonodatel'stva v kontse XX-nachale XXI vekov: monografiya. Barnaul: Altay State University Pub.

Baudoin, Marie-Elisabeth. 2006. "Is the Constitutional Court the Last Bastion in Russia against the Threat of Authoritarianism?” Europe-Asia Studies 58: 679-699.

Bowring, Bill. 2013. Law, Rights and Ideology in Russia. Landmarks in the Destiny of a Great Power. New York: Routledge.

Butler, William. 1991. Basic Documents on the Soviet Legal System. 2nd ed. New York: Oceana Pubns.

Dolzhikov, Alexey. 2012. "The European Court of Human Rights on the Principle of Proportionality in 'Russian' Cases". TEISE 82: 215-224.

Ebzeyev, Boris. 2000. Kommentarii $k$ postanovleniyam Konstitutsionnogo Suda Rossiyskoy Federatsii. Volume 1. Moscow: Yurist.

Fogelklou, Anders. 2003. "Constitutionalism and the Presidency in the Russian Federation". International Sociology 18: 181-198.

Frankenberg, Gunter. 2006. "Comparing Constitutions: Ideas, Ideals, and Ideology - toward a Layered Narrative". International Journal of Constitutional Law 3: 439-459.

Gadgiev, Gadis. 2004. Konstitutsionnye printsipy rynochnoy èkonomiki. (Razvitie osnov grazhdanskogo prava v resheniyakh Konstitutsionnogo Suda Rossiyskoy Federatsii). Moscow: Yurist.

Gadzhiyev, Gadis. 1999. "Pravovye pozitsii Konstitutsionnogo Suda Rossiyskoy Federatsii kak istochnik konstitutsionnogo prava". Konstitutsionnoe pravo: vostochnoevropeyskoe obozrenie 3: 81-95.

Greer, Steven. Luzius Wildhaber. 2012. "Revisiting the Debate about 'constitutionalising' the European Court of Human Rights". Human Rights Law Review 12: 655-687.

Henderson, Jane. 2007. "The Russian Constitutional Court and the Communist Party Case: Watershed or Whitewash". Communist and Post-Communist Studies 40: 1-16. 
Khorunzhij, Sergey. 2014. "Konstitutsionnaya ideologiya kak èlement pravovoy sredy". Gosudarstvennaya vlast' i mestnoe samoupravlenie 10: 3-5.

Kryazhkov, Vladimir. 1999. Konstitutsionnoe pravosudie v subyektakh Rossiyskoy Federatsii: pravovye osnovy i praktika. Moscow: Formula prava.

Mańko, Rafał. 2005. "The Culture of Private Law in Central Europe After Enlargement: A Polish Perspective". European Law Journal 11: 527-548.

Mańko, Rafał. 2013. "Weeds in the Gardens of Justice? The Survival of Hyperpositivism in Polish Legal Culture as a Symptom/Sinthome". Journal of Law, Literature and Culture 7(2): 207233.

Marchenko, Mikhail. 2011. Sudebnoe pravotvorchestvo i sudeyskoe pravo. Moscow: Prospect.

Morshchakova, Tamara. 1995. Sudebnaya reforma: yuridichesky professionalizm i problemy yuridicheskogo obrazovaniya. Moscow: Prior.

Nesmeianova, Svetlana. 2004. Konstitutsionny sudebny kontrol'v Rossiyskoy Federatsii: problemy teorii i praktiki. Ekaterinburg: Ural State Law Academy Publisher.

Pojarkov, Sergey. 2013. "Tsennostnye osnovaniya ideologii rossiyskogo konstitutsionalizma". Konstitutsionnoe i munitsipal'noe pravo 6: 18-20.

Polyakov, Leonid. 2007. “'Suverennaya demokratiya': politichesky fakt kak teoreticheskaya predmetnost"'. Obshchestvennye nauki i sovremennost' 2: 59-68.

Richardson, James. Marat Shterin. 2008. "Constitutional Courts in Postcommunist Russia and Hungary: How Do They Treat Religion?" Religion, State and Society 36: 251-267.

Rosenfeld, Michel. 1998. Just Interpretations: Law Between Ethics and Politics. California: University of California Press.

Sadurski, Wojciech. 2012. Constitutionalism and the Enlargement of Europe. Oxford: Oxford University Press.

Scheppele, Kim Lane. 2003. "Constitutional Negotiations: Political Contexts of Judicial Activism in Post-Soviet Europe”. International Sociology 18(1): 219-238.

Trochev, Alexei. 2011 Judging Russia. The Role of the Constitutional Court in Russian Politics 1990-2006. Cambridge: Cambridge University Press.

Van de Heyning, Catherine. 2012. "The Natural 'Home' of Fundamental Rights Adjudication: Constitutional Challenges to the European Court of Human Rights". Yearbook of European Law 31(1): 112-127.

Varga, Csaba. 2014. "The Changing Judicial Patterns in Central Europe". Acta Juridica Hungarica 55(2): 87-106.

Wildhaber, Luzius. 2007. "The European Convention on Human Rights and International Law". International and Comparative Law 56(2): 217-231.

Zorkin, Valery. 2013. Pravo v usloviyakh global'nykh peremen: monografiya. Moscow: Norma.

\section{Internet sources}

Belov, Sergey. 2014. Soblyudenie sudami pravovykh pozitsy Konstitutsionnogo Suda RF, svyazannykh s tolkovaniem deystvuyushchego zakonodatel'stva. http://monitoring.law.edu.ru/kategorii del/ processualnoe_pravo/soblyudenie_sudami_pravovyh_pozicij_konstitucionnogo_suda_rf_ svyazannyh_s_tolkovaniem_dejstvuyuwego_zakonodatelstva/ [Accessed: 19.12.2016].

Matczak, Marcin. 2016. Why Judicial Formalism is Incompatible with the Rule of Law. https://ssrn. com/abstract=2831477 [Accessed: 29.06.2019].

Novosti «Èkha Moskvy». Sud'ya Konstitutsionnogo Suda Anatoly Kononov pokidaet KS v nachale sleduyushchego goda. http://echo.msk.ru/news/638554-echo.html. [Accessed: 19.02.2017]. 